\title{
Studies on Cell Division in Regenerating Protoplasts of the Yeast Schizosaccharomyces japonicus
}

\author{
By MIROSLAV GABRIEL* AND MARIE KOPECKÁ \\ Department of Biology, Faculty of Medicine, J. E. Purkyně University, 66243 Brno, \\ Czechoslovakia
}

(Received 23 October 1987; revised 5 February 1988)

\begin{abstract}
Regeneration of the cell wall in yeast protoplasts can be blocked by the action of snail enzymes. Electron microscopic studies of protoplasts of Schizosaccharomyces japonicus var. versatilis showed that incubation in the presence of snail enzymes resulted in the production of incomplete cell walls consisting of $\alpha-(1 \rightarrow 3)$-glucan microfibrils aggregated into flat sheets of irregular size. This incomplete cell wall did not allow the formation of a septum and subsequent cell division. In contrast, protoplasts of the same yeast species growing in a flattened state produced by physical constraint formed incomplete walls that permitted cytokinesis but not reversion of the protoplasts to normal cells. These incomplete walls comprised three structural components: (i) a continuous network of long $\beta$-( $1 \rightarrow 3)$-glucan microfibrils; (ii) short $\alpha$-(1 $\rightarrow 3)$-glucan microfibrils; and (iii) an amorphous matrix. This ultrastructural picture corresponded to the first stages of regeneration (reached after $2-3 \mathrm{~h}$ incubation) leading to a complete cell wall; the walls in the flattened protoplasts, however, were not completed and consequently the protoplasts did not revert to normal cells.
\end{abstract}

\section{INTRODUCTION}

Previous papers on yeast protoplast regeneration have suggested that cytokinesis in a protoplast and its reversion to a cell can occur only after the cell wall has been completely regenerated (e.g. Nečas, 1971; Nečas \& Svoboda, 1981, 1985).

Protoplasts of the budding yeast Saccharomyces cerevisiae need to be cultivated in gel media for regeneration of a complete, morphogenetically active cell wall (Nečas, 1961, 1962; Svoboda, 1966). This wall comprises a fibrillar component that is masked by an amorphous matrix (Nečas, 1965; Nečas \& Svoboda, 1967; Svoboda \& Nečas, 1970). When cultivated in liquid media, protoplasts of $S$. cerevisiae form only an incomplete cell wall consisting of fibrillar nets made of the insoluble polysaccharides $\beta$-(1 $\rightarrow 3$ )-D-glucan and chitin (Kreger \& Kopecká, 1973, $1976 a, b ;$ Kopecká \& Kreger, 1986). This incomplete wall does not allow reversion to a cell (e.g. Nečas, 1971).

In protoplasts of the fission yeast Schizosaccharomyces pombe (which do not require gel media for new wall regeneration; Svoboda, 1967), the formation of an incomplete cell wall can be experimentally induced by the use of lytic enzymes from snail (Helix pomatia) digestive juice (Havelková, 1972). This incomplete wall allowed growth and karyokinesis of the protoplasts, but cytokinesis and reversion to cells did not occur (Havelková \& Křípalová, 1980; Havelková, 1981).

These findings led to the proposal that only an osmotically resistant cell wall that has reached a certain stage of biological complexity is sufficient for renewal of cytokinesis. Cytokinesis and reversion were thus considered to be interrelated. However, time-lapse microcinematography of flattened protoplasts of Schizosaccharomyces japonicus var. versatilis revealed repeated cytokinesis of protoplasts (Gabriel, 1984). Although they possessed only incomplete cell walls, each protoplast was capable of forming a septum that separated the cytoplasmic contents and duplicated genomes (Gabriel, 1984).

By comparing structural differences between two types of incomplete cell walls, i.e. walls 
either capable or incapable of inducing cytokinesis of protoplasts, and by comparing them with the completely regenerated cell wall, we have attempted to find differences in the ultrastructure of the cell wall that are related to cytokinesis and reversion of regenerated protoplasts into normal cells.

\section{METHODS}

Strain. The yeast used in this study was Schizosaccharomyces japonicus var. versatilis, kindly provided by Professor H. J. Phaff, University of California, Davis, USA. It was grown on $2 \%(\mathrm{w} / \mathrm{v})$ malt extract agar, $\mathrm{pH} 5 \cdot 5$. Stock cultures were stored at $4{ }^{\circ} \mathrm{C}$.

Protoplast preparation and cultivation. Protoplasts were prepared from cells in the exponential phase of growth by using snail digestive enzymes (Gabriel, 1983; Gabriel \& Kopecká, 1983). After removal of the enzymes by centrifugation, protoplasts were washed with $0.6 \mathrm{M}$-mannitol.

For flattening protoplasts, a small droplet of the protoplast suspension (approximately $10^{4}$ protoplasts) was put on a cover-slip coated with a thin layer of malt extract agar. The cover-slip was carefully placed on a slide so that the agar layer became sandwiched in between. Capillary forces together with the weight of the cover-slip resulted in partial flattening of the protoplasts (Gabriel, 1983). The flattened protoplasts grew, formed incomplete cell walls, and underwent karyokinesis and septation (Gabriel, 1983, 1984). After 4, 7, 12 and $20 \mathrm{~h}$ of cultivation at $27^{\circ} \mathrm{C}$, protoplasts were removed by washing-off in $0.6 \mathrm{M}$-mannitol and centrifuged for $20 \mathrm{~min}$ at $1500 \mathrm{~g}$.

Protoplasts were incubated in the presence of snail enzymes by applying a layer of protoplasts suspended in 0.6 M-mannitol and $20 \%(\mathrm{w} / \mathrm{v})$ snail digestive enzymes to the surface of malt extract agar, osmotically stabilized by 0.6 M-mannitol, in Petri dishes. Protoplasts were collected after $4,7,12$ and $20 \mathrm{~h}$ incubation at $27^{\circ} \mathrm{C}$ and washed with mannitol as above.

A portion of protoplasts was incubated with snail enzymes for $7 \mathrm{~h}$; after the enzymes had been removed by centrifugation, the protoplasts were spread on malt extract agar and further cultivated; samples were then collected every hour to study the course of cell wall regeneration.

Specific enzymes used. The $\beta$-(1 $\rightarrow 3)$-glucan component of the cell wall was identified by using purified endo- $\beta$ 1,3-glucanase from $S$. japonicus var. versatilis (Kopecká et al., 1974a, b). The enzyme solution $\left(0.5 \mathrm{U} \mathrm{ml}^{-1}\right.$ in sodium succinate buffer, pH 5.0) was kindly provided by Professor H. J. Phaff, University of California, Davis, USA. Zymolyase, in the form of purified endo-1,3- $\beta$-D-glucan hydrolase from Arthrobacter luteus (Kirin Labs), was kindly provided by Dr G. H. Fleet, University of New South Wales, Kensington, Australia. The $\alpha-(1 \rightarrow 3)$-glucan component was identified using $\alpha$-1,3-glucanase isolated from Trichoderma viride (de Vries \& Wessels, 1973), kindly sent to us by Dr O. M. H. de Vries (University of Groningen, The Netherlands). The latter two enzymes were diluted to $3 \mathrm{mg} \mathrm{ml}^{-1}$ in citrate/phosphate buffer, $\mathrm{pH} 5 \cdot 5$.

The enzymes were applied to wall structures isolated by osmotic lysis. The wall material was washed five times by centrifugation in distilled water and incubated at $37^{\circ} \mathrm{C}$ with the enzyme solutions $(1 \mathrm{mg}$ dry wt per $0.5 \mathrm{ml}$ solution). Bacterial contamination was prevented by adding a crystal of sodium azide. Samples were taken after 2 and $20 \mathrm{~h}$ of enzyme action and washed twice by centrifugation in distilled water. Part of each sample was extracted with $0.5 \%$ SDS $\left(50^{\circ} \mathrm{C}, 10 \mathrm{~min}\right.$; Gabriel \& Kopecká, 1983).

Electron microscopy. All samples were washed with distilled water five times. A drop of each was placed on a copper grid covered by a Formvar film. After drying the samples were shadowed with platinum at an angle of $15^{\circ}$ and photographed in a Tesla BS 500 electron microscope.

\section{RESULTS}

\section{Ultrastructure of isolated incomplete walls of flattened dividing protoplasts}

The incomplete walls consisted of continuous, rather dense fibrillar networks found at both early $(4$ to $7 \mathrm{~h})$ and late $(20 \mathrm{~h})$ stages of protoplast growth (Fig. 1). The networks comprised long microfibrils grouped into flat bundles. Although a major part of the fibrillar networks was masked by the amorphous matrix, the fibrillar texture always predominated, never being completely covered by the matrix. In some areas of the walls, short microfibrils could be identified. Differences in the appearance of walls between protoplasts from various samples or experiments were only quantitative (density of nets, size of empty meshes in the nets, amount of interfibrillar material etc.). A detailed study of how the septum was attached to the incomplete wall could not be made since these areas were obscured by the amorphous material.

\section{Ultrastructure of isolated incomplete cell walls assembled on the protoplasts in the presence of snail enzymes}

The incomplete walls consisted of short microfibrils assembled and intermeshed into flat sheets (Fig. 2). No regular pattern could be seen in the arrangement of microfibrils in the sheets. 


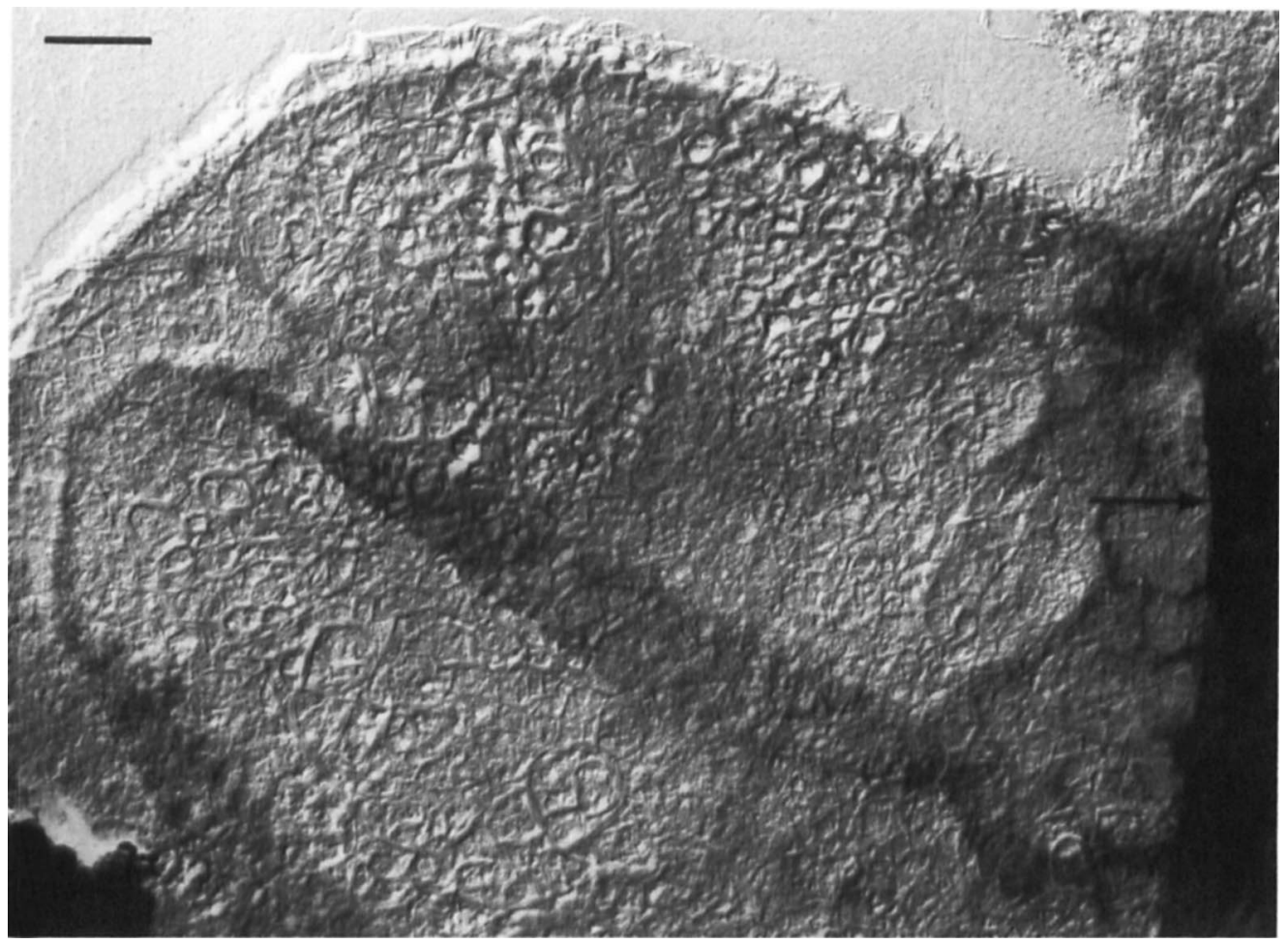

Fig. 1. Incomplete cell wall of flattened $S$. japonicus var. versatilis protoplast cultivated on the surface of malt extract agar for $20 \mathrm{~h}$ between a cover-slip and a slide. The arrow indicates a septum developing between two protoplasts. Bar, $1 \mu \mathrm{m}$.

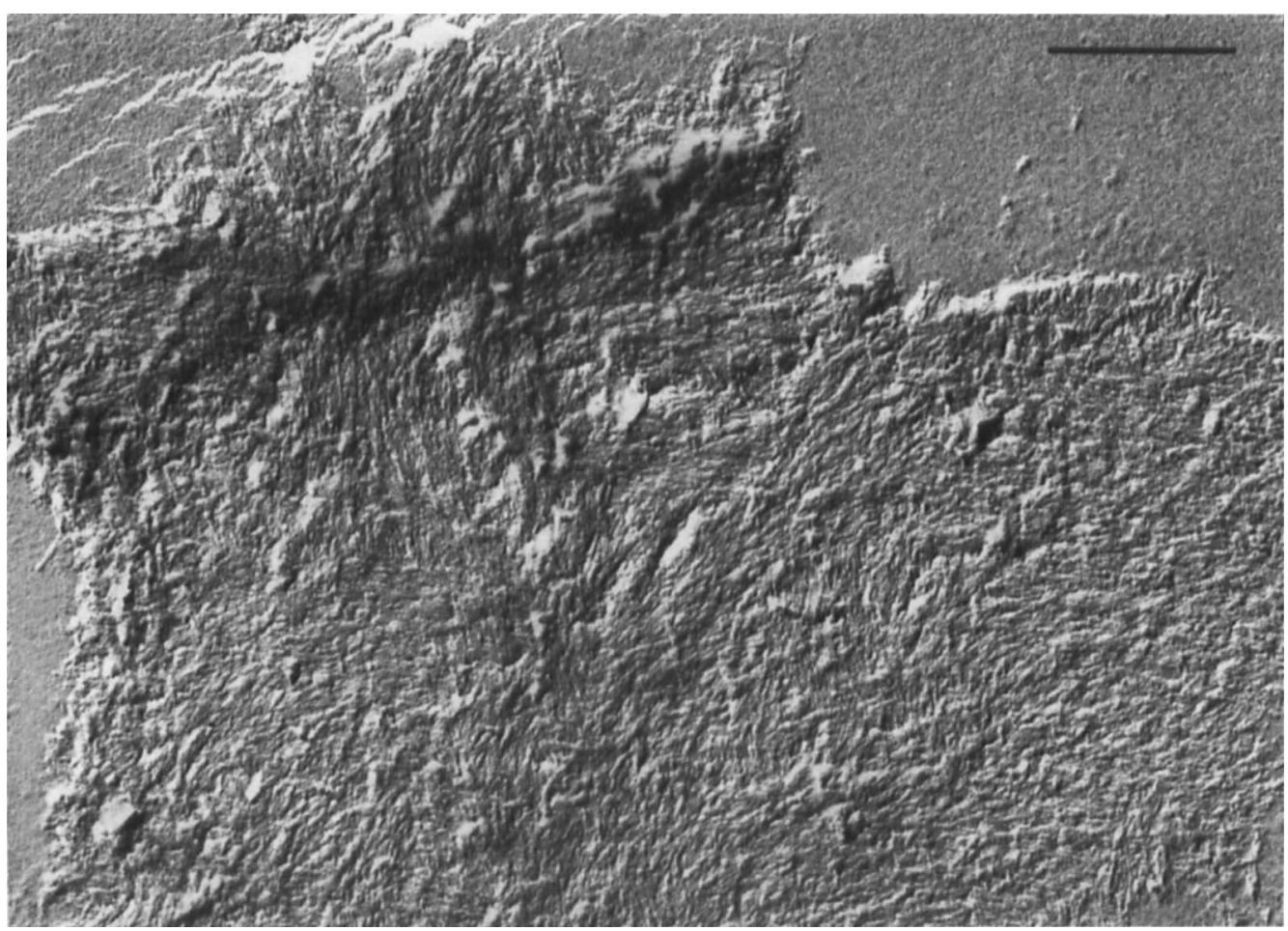

Fig. 2. Incomplete protoplast wall formed during $12 \mathrm{~h}$ incubation of protoplasts in nutrient medium with snail enzymes. Bar, $1 \mu \mathrm{m}$. 


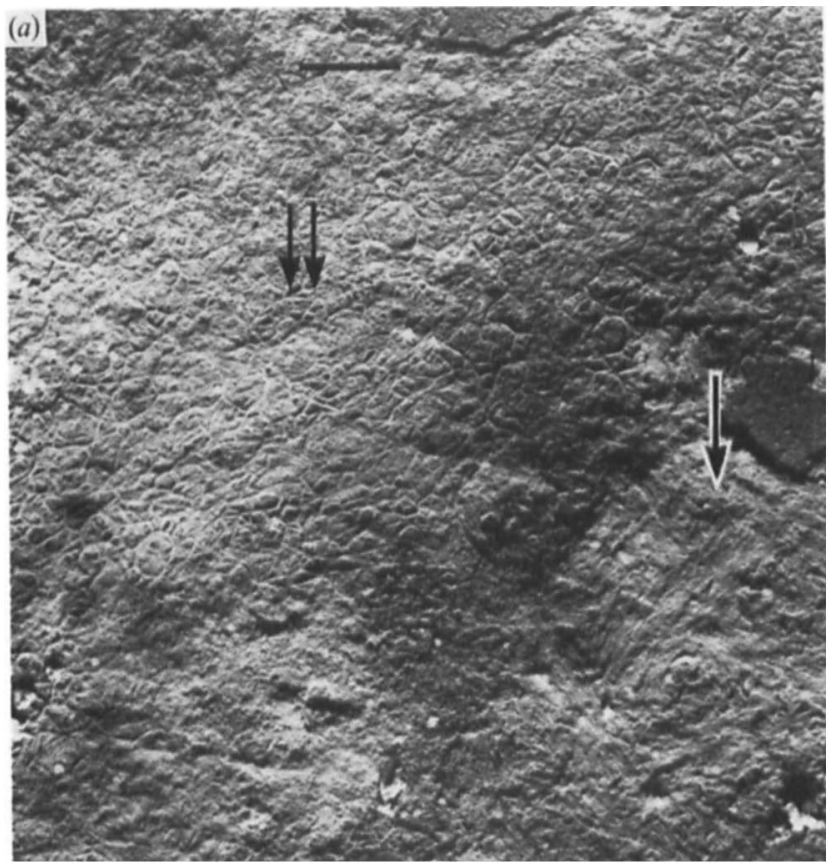

(c)

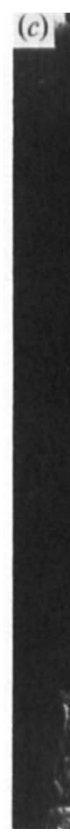

Fig. 3. Development of the protoplast cell wall. Protoplasts were incubated with snail enzymes for $7 \mathbf{h}$, and, after the enzymes had been removed by centrifugation, were spread on malt extract agar and further incubated without snail enzymes. Samples were collected as follows. (a) After $1 \mathrm{~h}$ incubation on malt extract agar. Flat sheets consisting of short microfibrils (arrow), produced by the protoplast in the presence of snail enzymes, were partly included into the newly regenerating cell wall consisting of fibrillar networks of long microfibrils (double arrows). (b) After $1 \mathrm{~h}$ incubation on malt extract agar. Fibrillar network of long microfibrils partly masked by other wall components but without the flat sheets of short microfibrils made in the presence of snail enzymes. (c) After $2 \mathrm{~h}$ incubation on malt extract agar. Regenerated but still incomplete cell wall, showing a developing septum (arrow). (d) After $3 \mathrm{~h}$ incubation on malt extract agar. Regenerated cell wall of a protoplast. $(e)$ After $5 \mathrm{~h}$ incubation on malt extract agar. Completely regenerated cell wall. Bars, $1 \mu \mathrm{m}$. 

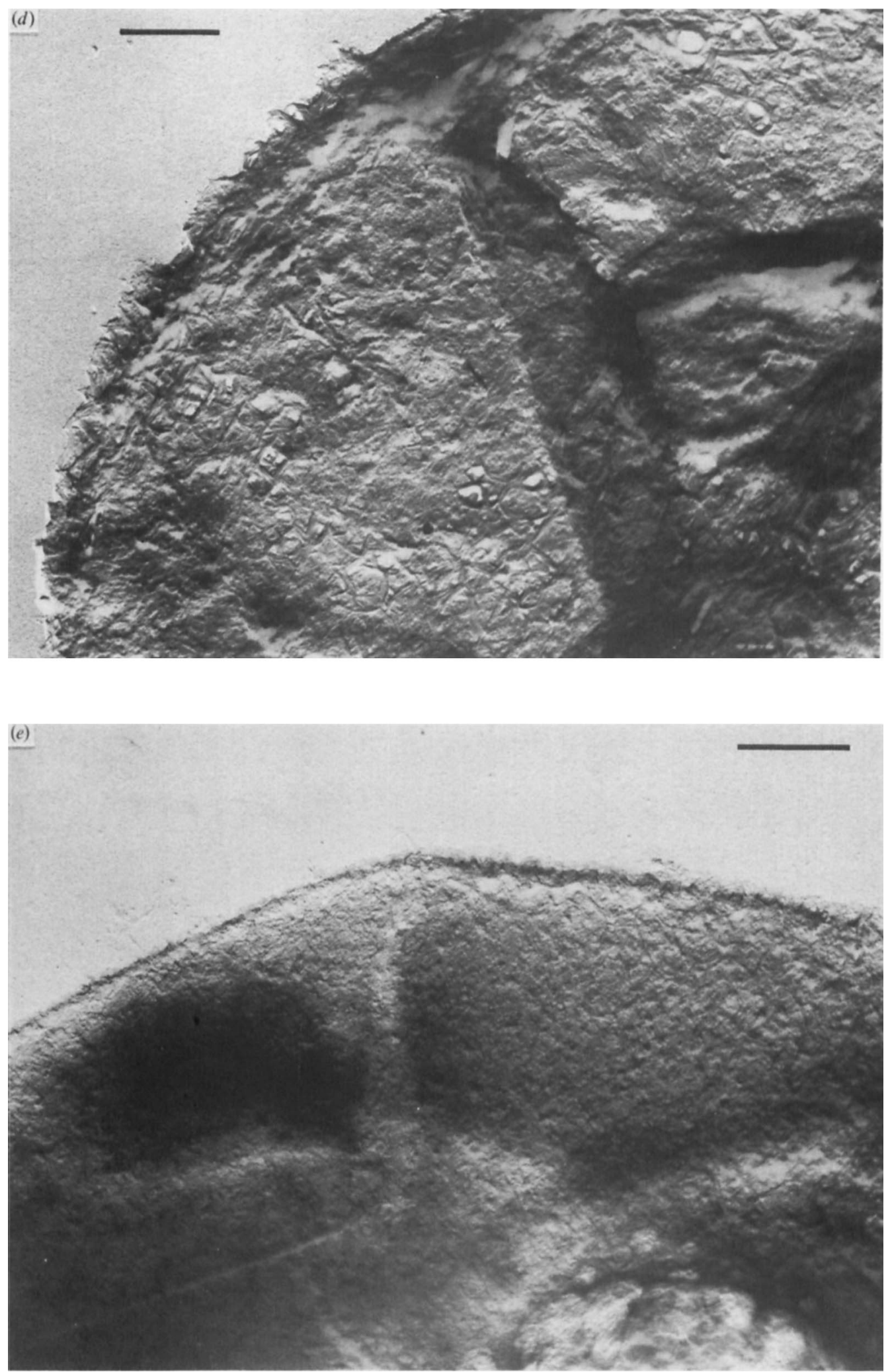

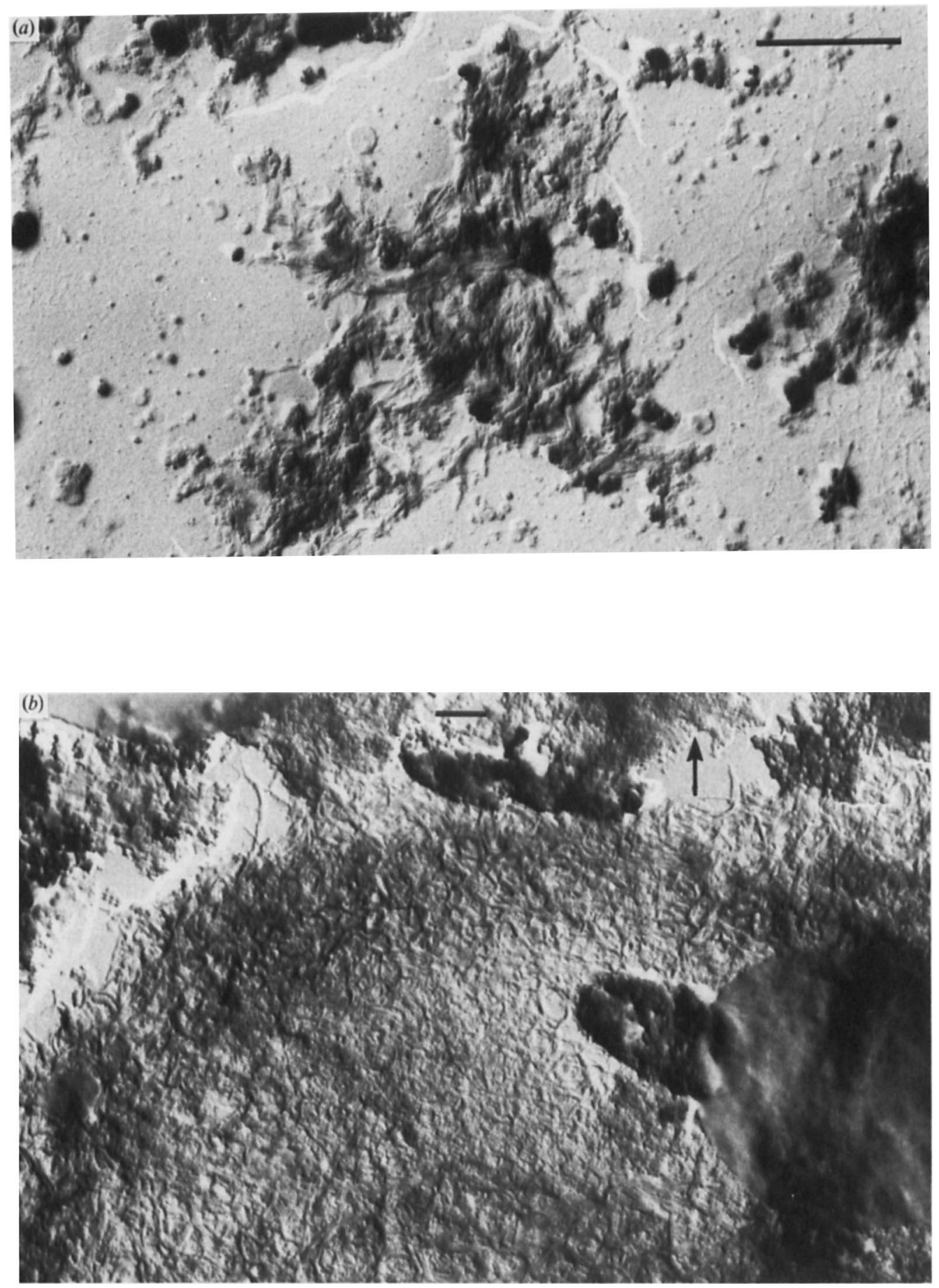

Fig. 4. Walls of regenerated protoplasts. (a) After $4 \mathrm{~h}$ incubation on malt extract agar without snail enzymes. The wall was treated with purified $\beta$-1,3-glucanase, which digested the walls almost completely. (b) After $4 \mathrm{~h}$ incubation of protoplasts on malt extract agar treated with $\alpha$-1,3-glucanase from Trichoderma viride. Short microfibrils released from the walls and partly degraded (arrow) are visible. Bars, $1 \mu \mathrm{m}$. 
This wall material was very fragile. After isolation by lysis in distilled water it did not keep the original shape of the protoplasts, but fragmented into irregular pieces. This material further fragmented during removal of the cytoplasm with SDS.

\section{Ultrastructure of newly regenerated cell walls after removal of snail enzymes}

The regenerated cell wall was formed either by incorporation of new wall components into the microfibrillar sheets produced during incubation with snail enzymes, or independently of this material. If flat sheets of aggregated short microfibrils were seen (Fig. $3 a$, arrow), they could be partly included into the newly regenerating cell wall consisting at this stage of long microfibrils arranged in a dense continuous pattern (Fig. $3 a$, double arrows). The isolated wall structure retained the shape of protoplasts exposed to snail enzymes. More often, however, regenerated wall structure was unrelated to the initial flat microfibrillar sheets made during incubation with snail enzymes (Fig. $3 b$ ). After $1 \mathrm{~h}$, long microfibrils aggregated into flat bundles were gradually masked by interfibrillar material which, after $2 \mathrm{~h}$, developed into a rigid support, isodiametric in shape (Fig. 3c). From this time, walls with developing septa could be found. After $3 \mathrm{~h}$ regeneration, the fibrillar texture became even more masked by matrix (Fig. $3 d$ ) $; 2$ to $3 \mathrm{~h}$ later wall regeneration was complete and the cell walls resembled those of yeast cells capable of reversion (Fig. $3 e$ ).

\section{Effect of purified $\beta$-1,3- and $\alpha-1,3-$ glucanases on wall structures of regenerating protoplasts}

Purified endo- $\beta-1,3$-glucanases destroyed the fibrillar networks, giving rise to irregular wall fragments (Fig. 4a). This suggests that the long microfibrils forming the network around the protoplast consist of $\beta-(1 \rightarrow 3)$-glucan, and are necessary for the integrity of the cell wall architecture.

In contrast, $\alpha$-1,3-glucanase digested only short microfibrils and also partially removed amorphous material, revealing the fibrillar network of long $\beta$-( $1 \rightarrow 3)$-glucan microfibrils aggregated in flat bundles (Fig. $4 b$ ). It can therefore be inferred that the short microfibrils are made of $\alpha-(1 \rightarrow 3)$-glucan.

\section{DISCUSSION}

Protoplasts of $S$. japonicus var. versatilis incubated in medium containing snail enzymes formed only incomplete walls consisting of short $\alpha-(1 \rightarrow 3)$-glucan microfibrils assembled into flat sheets. This was consistent with the absence of $\alpha-1,3$-glucanase (de Vries \& Wessels, 1973) and the presence in snail enzymes of $\beta$-1,3-glucanase (Phaff, 1971), which prevents the formation of long microfibrils of $\beta$ - $(1 \rightarrow 3)$-glucan. This wall structure fragmented on protoplast lysis, and was incapable of sustaining morphogenetic function and cytokinesis. In contrast, protoplasts of the same species grown in a flattened state caused by physical constraint (Gabriel, 1983) produced wall structures containing both short $\alpha-(1 \rightarrow 3)$-glucan microfibrils and a continuous fibrillar network made up of $\beta$ - $(1 \rightarrow 3)$-glucan masked by an amorphous matrix. These incomplete walls can induce septation and subsequent division, but not reversion of the protoplasts into normal cells (Gabriel, 1983, 1984).

Analogous short microfibrils of $\alpha-(1 \rightarrow 3)$-glucan have been demonstrated by X-ray diffraction in Schizosaccharomyces pombe protoplasts cultured in the presence of snail enzymes, whilst long $\beta$-(1 $\rightarrow 3)$-D-glucan microfibrils forming networks were seen in the first stage of wall regeneration without snail enzymes (Kreger \& Kopecká, 1978). Neither of these wall components alone, however, could induce cytokinesis. Protoplasts of both $S$. pombe and $S$. japonicus var. versatilis grown in medium with snail enzymes lack the amorphous matrix, presumably because of its degradation by the snail enzyme lytic complex, which contains a wide range of enzyme activities (cf. Phaff, 1971).

In flattened $S$. japonicus var. versatilis protoplasts three wall components were seen : a fibrillar network consisting of flat bundles of long $\beta$ - $(1 \rightarrow 3)$-glucan microfibrils, short $\alpha-(1 \rightarrow 3)$-glucan microfibrils and an amorphous matrix. This wall structure corresponds to the first stages of normal cell wall regeneration on the surface of solid media, as described previously (Gabriel \& Kopecká, 1983). Upon regeneration of a new cell wall, both in freshly prepared protoplasts (Gabriel \& Kopecká, 1983) and in those previously exposed to the action of snail enzymes in 
nutrient medium, these three components provide a basis for the development of a complete, rigid cell wall capable of normal morphogenetic function. In flattened protoplasts, however, the cell wall is not completed and, consequently, reversion did not occur. This implies that the reversion of a yeast protoplast to a normal cell is dependent upon the prior completion of the cell wall.

It is not known why in flattened $S$. japonicus var. versatilis protoplasts the cell wall is not completed in spite of the three basic wall components having been formed. One of the reasons may be the rapid growth of the cytoplasm of flattened protoplasts in contrast to a relatively slow rate of wall regeneration, as suggested by the results of time-lapse microcinematography (Gabriel, 1984). The change in the cell surface : volume ratio due to flattening may also play a role. The inability of a protoplast to complete cell wall regeneration may also be due to the shortage of polysaccharides available for wall assembly. If each cell had a fixed amount of polysaccharide synthetases to build its cell wall, determined genetically for a constant cell volume, the increase in protoplast surface caused by flattening could result in there being insufficient synthetases to make the polysaccharides required for a complete cell wall during the time available.

Microcinematographic studies of growing $S$. japonicus var. versatilis protoplasts have shown that the formation of the septum in this species proceeds in a centripetal manner, beginning from the wall components outside the plasma membrane (Gabriel, 1984). The absence of a sufficiently rigid wall in regenerating protoplasts exposed to snail enzymes may result in lack of septum formation, but equally we have not excluded the possibility that snail enzymes degrade the septum. We have shown, however, that cytokinesis (septation) can be initiated during regeneration with wall structures that are significantly less complete than those with the level of organization required to allow full reversion to normal cells.

\section{REFERENCES}

GABRIEL, M. (1983). Karyokinesis and cell septum formation during incomplete cell wall regeneration in flattened Schizosaccharomyces versatilis protoplasts. In Proceedings of 6th European Cell Cycle Workshop Progress in Cell Cycle Controls, Prague 1983, pp. 144-146. Edited by J. Chaloupka, A. Kotyk \& E. Streiblová. Prague: Institute of Microbiology Czechoslovak Academy of Sciences.

GABRIEL, M. (1984). Karyokinesis and septum formation during the regeneration of incomplete cell walls in protoplasts of Schizosaccharomyces japonicus var. versatilis: a time-lapse microcinematographic study. Journal of General Microbiology 130, 625-630.

GABRIEL, M. \& KOPECKÁ, M. (1983). Regeneration of the cell wall of protoplasts of the fission yeast Schizosaccharomyces versatilis in liquid media and their reversion to cells. Folia microbiologica 28, 452457.

HaVelková, M. (1972). Experimental inhibition of cell wall formation and of reversion in Nadsonia elongata and Schizosaccharomyces pombe protoplasts. Protoplasma 75, 405-419.

HAVELKovÁ, M. (1981). Multiple septation in multinucleate protoplasts of Schizosaccharomyces pombe. Zeitschrift für Allgemeine Mikrobiologie 21, 261266.

HaVelková, M. \& Krí́palová, J. (1980). Independence of nuclear cycle on cell wall regeneration in Schizosaccharomyces pombe protoplasts. Folia microbiologica 25, 219-224.

KOPECKÁ, M. \& KREGER, D. R. (1986). Assembly of microfibrils in vivo and in vitro from $(1 \rightarrow 3)-\beta$-Dglucan synthesized by protoplasts of Saccharomyces cerevisiae. Archives of Microbiology 143, 387-395.

Kopecká, M., Phaff, H. J. \& Fleet, G. H. (1974a).

Demonstration of a fibrillar component in the cell wall of the yeast Saccharomyces cerevisiae and its chemical nature. Journal of Cell Biology 62, 66-76.

Kopecká, M., Phaff, H. J. \& Fleet, G. H. (1974b). The ultrastructure of the yeast cell wall after enzymic degradation by purified enzymes. In Proceedings of the Fourth International Symposium on Yeasts, Vienna, Austria, part I, pp. 205-206. Edited by H. Klaushofer \& U. B. Sleytr. Vienna: Hochschülerschaft an der Hochschule für Bodenkultur.

KREGER, D. R. \& KOPECKÁ, M. (1973). On the nature of fibrillar nets formed by protoplasts of Saccharomyces cerevisiae in liquid media. In Yeast, Mould and Plant Protoplasts, pp. 117-130. Edited by J. R. Villanueva, I. García-Acha, S. Gascón \& F. Uruburu. London: Academic Press.

KREGER, D. R. \& KoPECKÁ, M. (1976a). On the nature and formation of the fibrillar nets produced by protoplasts of Saccharomyces cerevisiae in liquid media : an electronmicroscopic X-ray diffraction and chemical study. Journal of General Microbiology 92, 207-220.

KREGER, D. R. \& KoPeCKÁ, M. (1976b). Assembly of wall polymers during the regeneration of yeast protoplasts. In Microbial and Plant Protoplasts, pp. 237-252. Edited by J. F. Peberdy, A. H. Rose, H. J. Rogers \& E. C. Cocking. London: Academic Press.

KREGER, D. R. \& KOPECKÁ, M. (1978). The nature of the nets produced by protoplasts of Schizosaccharomyces pombe during the first stage of wall regeneration in liquid media. Journal of General Microbiology 108, 269-274.

NeČAs, O. (1961). Physical conditions as important factors for the regeneration of naked yeast protoplasts. Nature, London 192, 580-581. 
NEČAS, O. (1962). The mechanism of regeneration of yeast protoplasts. Physical conditions. Folia biologica 8, 256-262.

NeČAS, O. (1965). Mechanism of regeneration of yeast protoplasts. Folia biologica 11, 371-377.

NEČAS, O. (1971). Cell wall synthesis in yeast protoplasts. Bacteriological Reviews 15, 149-170.

NEČAS, O. \& SvOBODA, A. (1967). Relation between the biosynthesis of the cell wall and regeneration in yeast protoplasts. In Symposium über Hefe-Protoplasten, pp. 67-71. Edited by R. Müller. Berlin: AkademieVerlag.

NeČAS, O. \& SvoBODA, A. (1981). Morphogenesis in protoplasts. In Yeast Cell Envelopes: Biochemistry, Biophysics and Ultrastructure, vol. 2, pp. 105-127. Edited by W. N. Arnold. Boca Raton: CRC Press.

NeČAS, O. \& SvobodA, A. (1985). Cell wall regeneration and protoplast reversion. In Fungal Protoplasts, pp. 115-133. Edited by J. F. Peberdy \& L. Ferenczy. New York: Marcel Dekker.

PHAFF, H. J. (1971). Structure and biosynthesis of the yeast cell envelope. In The Yeasts, vol. 2, pp. 135-
210. Edited by A. H. Rose \& J. S. Harrison. London \& New York: Academic Press.

SvoBoDA, A. (1966). Regeneration of yeast protoplasts in agar gels. Experimental Cell Research 44, 640642 .

SvoBODA, A. (1967). Regeneration ability of protoplasts of different yeast species. In Symposium über Hefe-Protoplasten, pp. 31-36. Edited by R. Müller. Berlin: Akademie-Verlag.

SvoBODA, A. \& NEČAS, O. (1970). Experimental decoupling in the synthesis of fibrillar and amorphous components during regeneration of the wall in Saccharomyces cerevisiae protoplasts. In Yeast Protoplasts, Proceedings of the Second International Symposium on Yeast Protoplasts, pp. 211-215. Edited by O. Nečas \& A. Svoboda. Brno: J. E. Purkyně University Press.

DE VRIES, O. M. H. \& Wessels, J. G. H. (1973). Release of protoplasts from Schizophyllum commune by combined action of purified $\alpha-1,3$-glucanase and chitinase derived from Trichoderma viride. Journal of General Microbiology 76, 319-330. 